\title{
Diminished expression of integrin adhesion molecules on human colonic epithelial cells during the benign to malign tumour transformation
}

\author{
A Stallmach, B v Lampe, H Matthes, G Bornhöft, E O Riecken
}

\begin{abstract}
Integrins are transmembrane molecules that mediate cell-cell and cell-substratum adhesion. Because alterations in the adhesive properties of tumour cells are thought to influence tumour cell invasion, the expression of integrin $\alpha$ and $\beta$ chains in 19 human colorectal carcinomas, eight adenomas, and eight normal colon tissues was examined immunohistochemically using an indirect immunofluorescent technique. Normal colonic epithelial cells were found to express the integrin $\alpha_{3}, \alpha_{5}, \alpha_{6}, \beta_{1}$, and $\beta_{4}$ chains, whereas the $\alpha_{2}$ chain was expressed only on epithelial cells lining the base of the crypts and was absent from cells lining the mouth of the crypts or the surface epithelium. No epithelial staining of the $\alpha_{1}, \alpha_{4}, \beta_{2}$, and $\beta_{3}$ chains was observed. A progressive reduction of all normally expressed $\alpha$ and $\beta$ chains was associated with increasing neoplastic transformation. The expression of the $\alpha_{3}$ and $\alpha_{5}$ chains was already noticeably reduced in adenomas, and was completely absent in most colonic carcinomas. In contrast, $\alpha_{6}, \beta_{1}$, and $\beta_{4}$ expression was maintained in adenomas, whereas the transformation from benign to malignant neoplasms associated with infiltrative growth was characterised by diminished or lost expression of $\alpha_{6}, \beta_{1}$, and $\beta_{4}$ chains. Thus, the decreased expression of integrins in human colon carcinomas may contribute to the altered adhesion and migration properties of these tumour cells.
\end{abstract}

Cancer of the large bowel, the second most common site for carcinomas in both men and women, accounts for about $20 \%$ of all deaths from malignant disease in western Europe. Unfortunately, the death rate for this disease has not changed significantly for the past 40 years. 'The propensity of malignant tumour cells to spread from their site of origin to other parts of the body is one of the principal reasons for the high rate of cancer mortality. If oncologists were able to treat metastatic disease or prevent the formation of metastases, the incidence of death would be substantially reduced. The ability of tumour cells to adhere to basement membranes is known to play a crucial role in the complex process of metastasis formation, ${ }^{2}$ and tumour cell adhesion to basement membranes has been shown to correlate with their ability to metastasise. ${ }^{3}$ The interaction of tumour cells and the extracellular matrix is mainly mediated through binding of extracellular matrix components to specific tumour cell surface adhesion receptors.

Integrins are transmembrane protein com- plexes consisting of non-covalently associated $\alpha$ and $\beta$ subunits. ${ }^{+}$They mediate both cell-substratum and cell-cell adhesion. ${ }^{5}$ As originally described, ${ }^{6}$ integrins were divided into three subfamilies, each with a common $\beta$ subunit capable of associating with a specific group of $\alpha$ subunits. More recent works have shown that there are at least 11 different $\alpha$ subunits and eight $\beta$ subunits, and that certain $\alpha$ subunits can combine with more than one $\beta$ subunit. ${ }^{7}$ The $\beta_{1}, \beta_{2}$, and $\beta_{3}$ subunits can associate with several distinct $\alpha$ subunits, and define the three integrin subfamilies - the VLA (very late activation antigens) protein family, the LEU-CAM (leucocyte cell adhesion molecule) family, and the cytoadhesions, respectively. ${ }^{8}$ The first subfamily comprises at least six related complexes, each consisting of a $\beta_{1}$ chain with a distinct $\alpha$ chain companion. Most of these integrins are promiscuous receptors because they bind to various matrix proteins. ${ }^{7}$ Members of the VLA subfamily include receptors for fibronectin (VLA-3, VLA-4, and VLA-5), laminin (VLA-1, VLA-2, VLA-3, and VLA-6) and collagen types I and IV (VLA-1, VLA-2, and VLA-3). ${ }^{10}$ However, VLA-5 and VLA-6 seem to be specific for fibronectin and laminin, respectively. ${ }^{711}$

The $\beta_{2}$ subfamily of integrins, also termed LEU-CAMs or the CD18 antigens, consists of three leukocyte adhesion receptors. ${ }^{7}$ The $\beta_{3}$ subfamily of integrins, also known as cytoadhesions, consists of vitronectin receptor $\left(\alpha \mathrm{v} / \beta_{3}\right)$ and the platelet glycoprotein IIb/IIIA $\left(\alpha_{\text {IIb }} / \beta_{3}\right)$ complex (reviewed in $\left.{ }^{7}\right)$ ).

It has previously been shown that epithelial cells express VLA-1, $-2,-3$, and -6 molecules in normal human small intestine. ${ }^{12}$ Recently, there has been increasing evidence for a pathological distribution of cell adhesion receptors, including members of the integrin family, in colonic carcinomas. ${ }^{131+}$ Since little is known about the molecular interaction of epithelial colonic cells and the extracellular matrix via integrins during the adenoma-carcinoma sequence in the large intestine, we have performed immunohistological staining for the integrins in human colorectal carcinomas in an attempt to compare their expression with that of precancerous adenomas and normal colonic mucosa.

\section{Methods}

TISSUES

Intestinal tissues were obtained from two different groups of patients. The first group comprised 19 patients, 12 men and seven women ranging from 37 to 84 years of age, with colo- 
rectal adenocarcinomas. Samples were obtained from patients with colorectal carcinomas that displayed differentiation of a high degree in four, of a moderate degree in 10 , and of a low degree in 5 cases according to the classification of Morson and Dawson. ${ }^{15}$ In eight cases, macroscopically and histologically normal adjacent mucosa (10 $\mathrm{cm}$ distant from the primary tumour) as well as tumour tissues were examined. The second group included eight patients with adenomas of the colon. Resection specimens were obtained immediately after surgery and tissue samples were snap frozen and stored in liquid nitrogen.

\section{IMMUNOHISTOLOGICAL TECHNIQUE}

The expression of VLA antigens in these tissues was examined by an indirect immunofluorescent technique. Cryostat sections $(6 \mu \mathrm{m})$ were air dried overnight and stored at $-20^{\circ} \mathrm{C}$. Sections were incubated with either $20 \mu$ l of each primary antibody or $0.2 \mathrm{~mol} / \mathrm{l}$ phosphate buffered saline (PBS), serving as a control, for 60 minutes in a humidified chamber. They were washed three times with $0.1 \mathrm{~mol} / 1 \mathrm{PBS}$ containing $0.2 \%$ bovine serum albumin, incubated for 30 minutes with at chain expression epithelial-mesenchym interface. (D) Poorly differentiated carcinoma. (Magnification $\times 200$.)

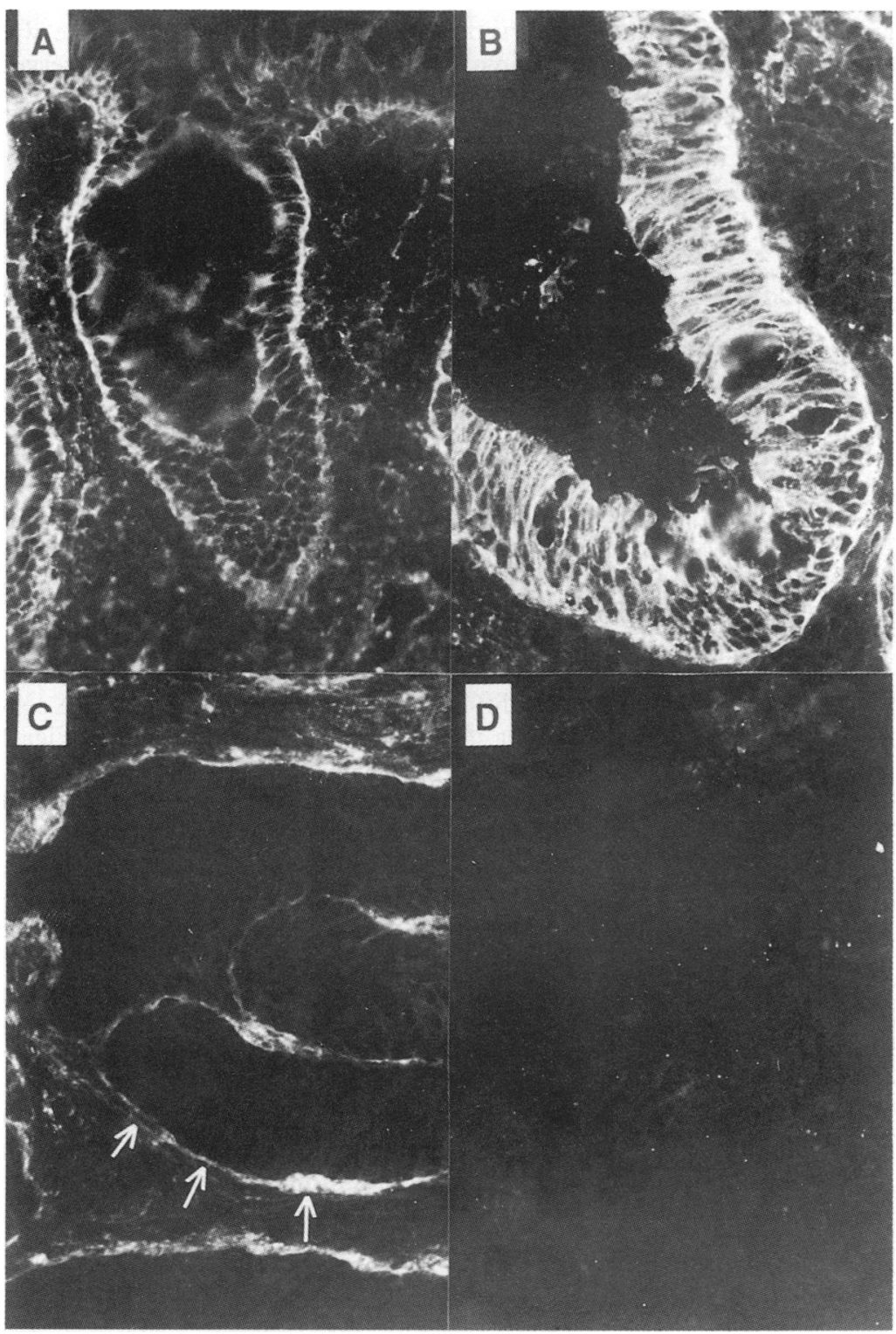

Receptor, structure, suggest ligands (collagen (col), laminin (lam), fibronectin (fn)) and specificity of the antibodies used

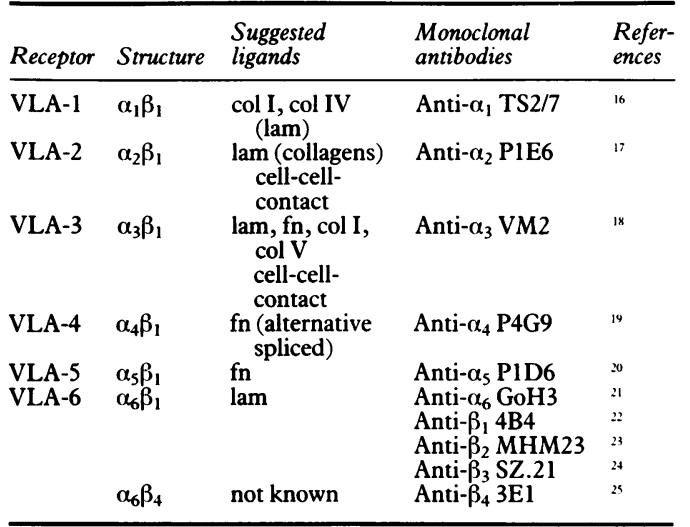

the Rhodamine conjugated secondary antibody and washed three times with PBS. The monoclonal antibodies used are listed in the Table. Antibody staining was examined with a Zeiss immunofluorescent microscope, and pictures were taken using an Agfa-Chrome 1000 ASA film. Staining of epithelial cells was graded semiquantitatively by a four point scale $(-=$ no or weak staining, $+=$ moderate,$++=$ strong, $+/-=$ moderate and unstained epithelial cells on the same section).

\section{STATISTICAL ANALYSIS}

For statistical analysis the grades of antigen expression were converted to numbers $(-=0$, $+/-=0 \cdot 5,+=1,++=2$ ) as described by MacDonald et al. ${ }^{26}$ Statistical significance was calculated using the Wilcoxon rank test and considered to be significant at the $\mathrm{p}<0.05$ level.

\section{Results}

IMMUNOFLUORESCENCE ANALYSIS OF INTEGRIN EXPRESSION IN NORMAL COLONIC MUCOSA

A comparable pattern of staining was seen in all eight specimens. Antibodies against $\alpha_{3}, \alpha_{5}, \alpha_{6}$, $\beta_{1}$, and $\beta_{4}$ showed brilliant staining of the epithelium in normal colonic mucosa. The $\alpha_{6}$ and $\beta_{4}$ expression were strongly accentuated on the basal epithelial cell membrane, while $\alpha_{3}, \alpha_{5}$, and $\beta_{1}$ were expressed more evenly on the cell surface. The $\alpha_{2}$ chain was expressed only on epithelial cells lining the base of the crypts, but was absent from cells lining the mouth of the crypts or the surface epithelium. Expression of $\alpha_{1}, \alpha_{4}, \beta_{2}$, and $\beta_{3}$ chains on epithelial cells was not detected by the used antibodies.

ADENOMAS

The expression of the $\alpha_{2}, \alpha_{6}$, and $\beta_{4}$ chains in colorectal adenomas was similar to that in normal mucosa. Moderate or strong expression of the $\alpha_{6}$ and $\beta_{4}$ chains was observed at the contact sites of the epithelial cells and basement membrane in all cases. Increased cytoplasmatic staining in epithelial cells of adenomas was observed when compared with the immunofluorescence pattern of controls (Fig 1). No statistical differences were observed when $\alpha_{6}$ and $\beta_{4}$ chain cell mem- 
Figure 2:

Immunohistological staining of the $\alpha_{5}$ chain in epithelial cells. (A) Normal colonic mucosa. (B) Tubulovillous adenoma. Arrows indicate negative epithelial cells. differentiated carcinoma. No positive staining of epithelial cells was seen using the monoclonal antibody against the $\alpha_{5}$ chain.

(Magnification $\times 200$. (C) Moderately

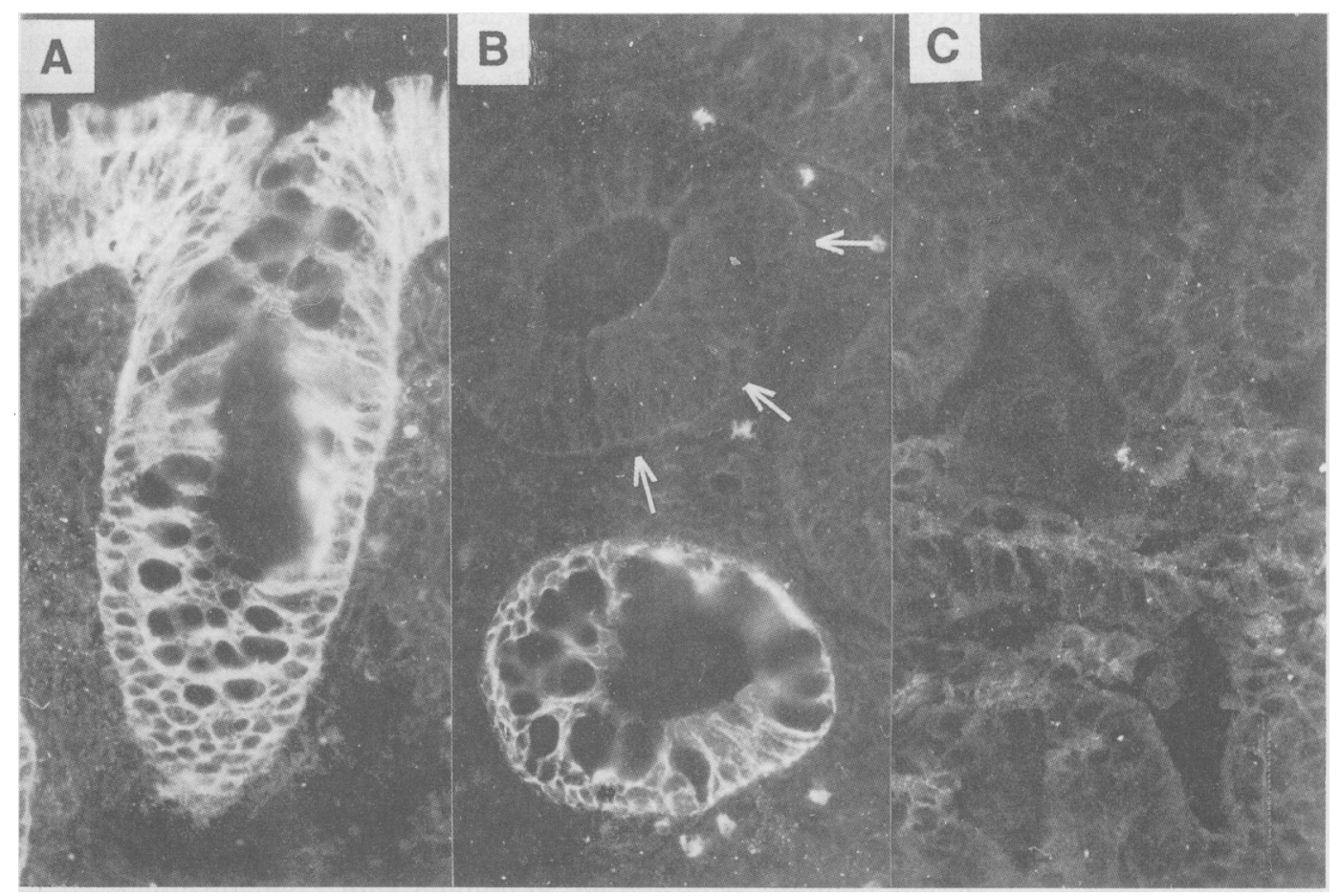

brane expression of epithelial cells of adenomas was compared with expression in normal colonic mucosa. In contrast, $\alpha_{3}$ and $\alpha_{5}$ chain expression in adenomas showed a noticeably altered pattern. Only in one case were the $\alpha_{3}$ and $\alpha_{5}$ chains expressed by all epithelial cells. In five cases, $\alpha_{3}$ expression showed a pattern of areas of stained epithelial cells mixed with areas of complete

Figure 3: Integrin adhesion molecule expression in

various colon disease states. Each symbol represents tissue from one patient. Intensity of $\alpha$ or $\beta$ chain expression on epithelial cells was graded as indicated in Methods.
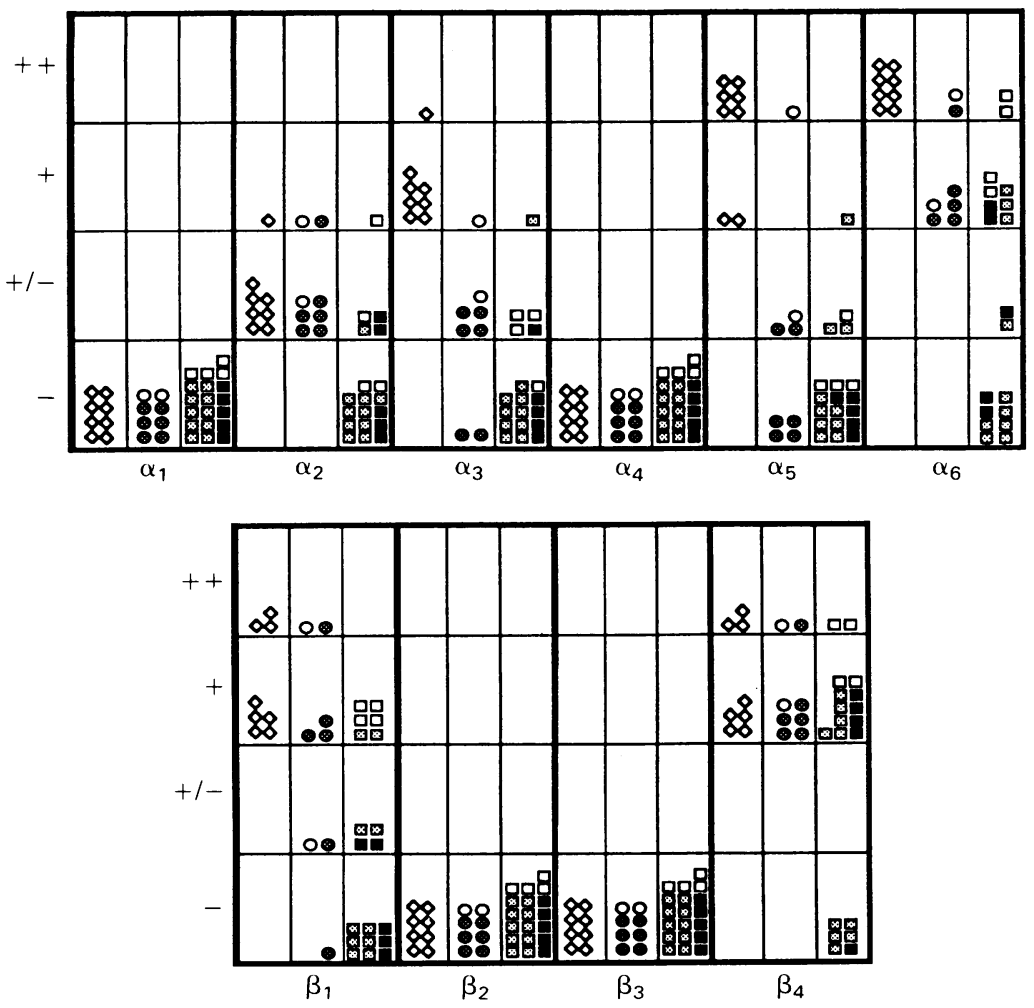

- Normal colonic mucosa $(n=8)$

- Adenoma, tubular $(n=2)$

- Adenoma, tubulo-villous $(n=6)$

- Carcinoma, well differentiated $(n=4)$

- Carcinoma, moderately differentiated $(n=10)$

- Carcinoma, poorly differentiated $\left(r_{1}=5\right)$ negative cells on the same section (Fig 2). A similar pattern for $\alpha_{5}$ chain expression was observed in three cases. In no other case was staining for $\alpha_{3}$ or $\alpha_{5}$ chain expression observed (see also Fig 3).

\section{COLORECTAL CARCINOMAS}

We found an obviously diminished expression of $\alpha_{2}, \alpha_{3}, \alpha_{5}, \alpha_{6}, \beta_{1}$, and $\beta_{4}$ chains in the 19 colorectal carcinomas tested. Epithelial staining for $\alpha_{3}$ and $\alpha_{5}$ chains similar to that seen in normal tissues was observed in only $1 / 19$ of the adenocarcinomas (see also Fig 3). Fourteen of them were completely negative for $\alpha_{3}$ chain antibodies and 15 for $\alpha_{5}$ chain antibodies (Fig 2). Diminished expression of $\alpha_{2}$ chain antibodies was also seen. In 14/19 cases no staining was observed, while at least $50 \%$ of epithelial cells showed moderate staining of VLA-2 in all adenomas and normal tissue samples.

The $\alpha_{6}, \beta_{1}$, and $\beta_{4}$ chains were moderately expressed by carcinoma cells in all (4/4) cases of well differentiated adenocarcinomas at the cellstroma interface as well as in adenomas (Figs 1 and 4). Upper cell layers were only weakly stained. Statistical analysis showed a significant reduction in the intensity of $\alpha_{6}$ chain expression in comparison with normal colonic mucosa $(p<0.05)$, whereas expression of $\beta_{1}$ and $\beta_{4}$ chains was not statistically different. In contrast, in $9 / 15$ cases of moderately or poorly differentiated carcinomas there was no detectable expression of the $\alpha_{6}$ chain (stained with $\mathrm{GoH} 3$ ), in $9 / 15$ cases there was no detectable expression of the $\beta_{1}$ chain (stained with 4B4), and in 6/15 cases there was no detectable expression of the $\beta_{4}$ chain (stained with $3 E 1$ ). Staining was seen in the other cases at the basal cell margin only and this was weaker than in normal tissue samples.

\section{Discussion}

The interaction of malignant cells with the 


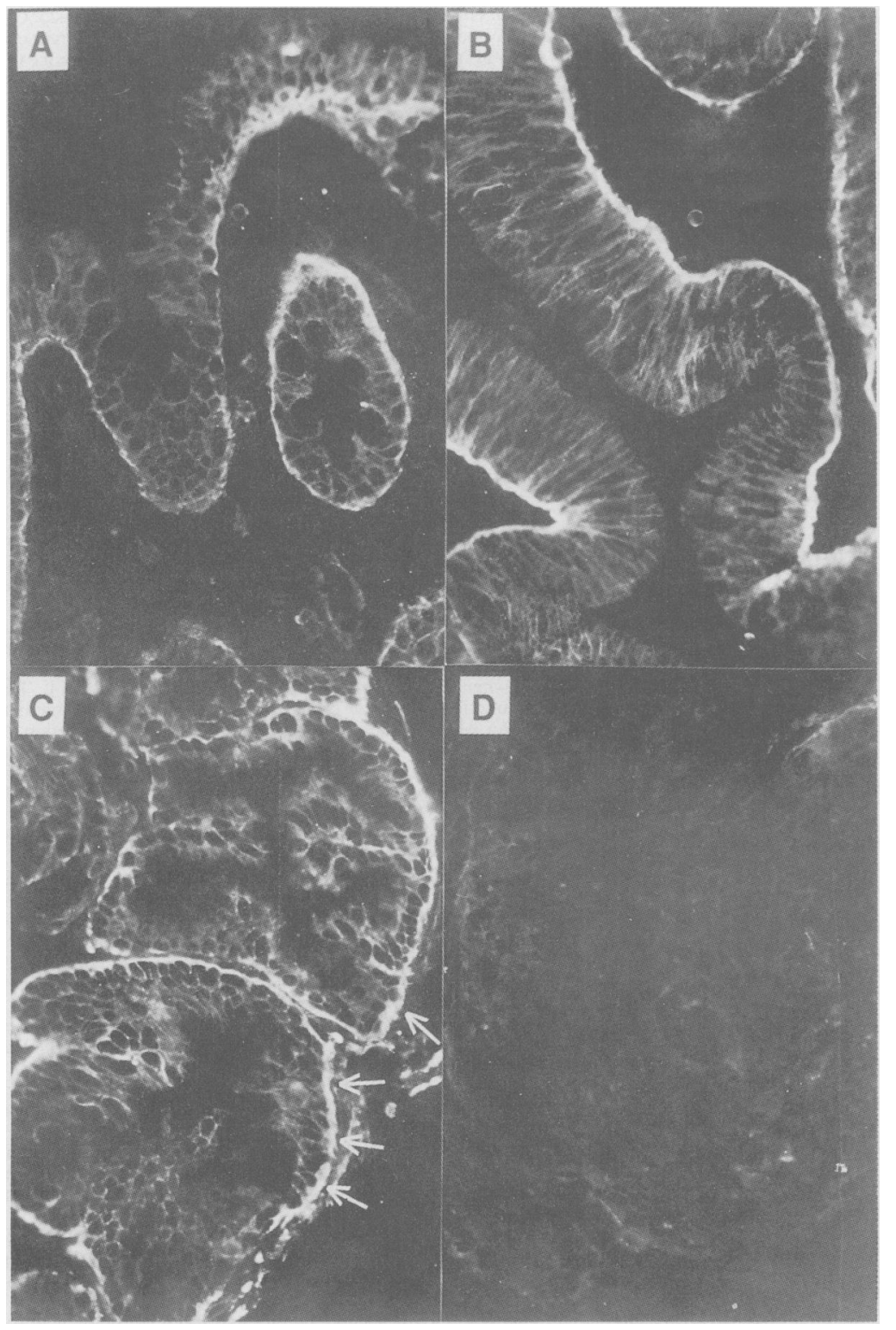

Figure 4:

Immunohistological staining of $\beta_{4}$ chain in epithelial cells. of $\beta_{4}$ chain in epithelial cells.
(A) Normal colonic mucosa. (A) Tormal colonic mucosa. (C) Well differentiated carcinoma. Arrows indicate $\beta_{4}$ chain expression at the epithelial-mesenchymal interface. (D) Poorly differentiated carcinoma. (Magnification $\times 200$.) surrounding extracellular matrix, especially with basement membranes, is known to play a crucial role in the complex mechanisms of tumour invasion and metastasis. ${ }^{2}$ Integrin molecules are involved in these interactions as they mediate cell adhesion to various components of the extracellular matrix.

In this study, we have analysed the expression of different $\alpha$ and $\beta$ chains of the integrins during the transformation of normal colonic mucosa via adenomas to invasive colorectal carcinomas. Our data show a significant loss of $\alpha_{3}$ and $\alpha_{5}$ chains of the VLA complexes in tubulovillous adenomas and colorectal carcinomas in comparison with normal colonic mucosa. The observation of a mixed pattern of $\alpha_{3}$ and $\alpha_{5}$ chain expression in adenomas is of particular interest. In some crypts, epithelial cells were positive, whereas in others were completely negative. It is possible that this immunohistological difference in the expression of cell adhesion components reflects different types of preneoplastic cells as well as neoplastic cells in tubulovillous adenomas. These findings confirm previous results of Pignatelli et al, who observed diminished expression of the $\alpha_{2}$ and $\alpha_{3}$ chains of the known collagen receptors VLA-2 and VLA-3 in moderately or poorly differentiated human colorectal cancers. ${ }^{1+}$ However, in this study, the expression of the $\alpha_{2}$ and $\alpha_{3}$ chains, and, in agreement with our results, of the $\beta_{1}$ chain, on epithelial cells of adenomas was unchanged in comparison with controls.

Furthermore, there was a significant correlation between reduced expression of the $\alpha_{6}$ chain of VLA-6, one of the known laminin receptors of the $\beta_{1}$ integrin family, and the transformation of adenomas to invasive carcinomas. The addition of the mAB GoH3 against the $\alpha_{6}$ chain of VLA- 6 inhibited binding of colon cancer derived HT 29 cells to laminin in cell adhesion assays completely (own unpublished results). Therefore, reduction of VLA-6 expression may allow the colonic carcinoma cells to detach from the basement membrane. Thus, the carcinoma cells and not the $\alpha_{6}$ positive adenoma cells would be able to infiltrate the underlying mesenchyme. It is possible that a diminished expression of VLA adhesion molecules as described for neoplastic colonic epithelial cells is a general phenomenon for cells attaining a malignant phenotype. A similar diminished expression of $\alpha_{2}, \alpha_{5}$, and $\beta_{1}$ chains in carcinomas of the breast and of $\alpha_{6}$ and $\beta_{4}$ chains in small cell lung cancers was reported recently. ${ }^{1627}$ An altered expression of these adhesion molecules may influence the aggressiveness of local infiltrative growth and metastasis in human cancers. This hypothesis is corroborated by in vitro studies. Giancotti et $a l^{28}$ observed that after transfection of the genetic information for $\alpha_{5} \beta_{1}$, the known fibronectin receptor of the VLA family, into malignant Chinese hamster ovary cells, these cells regained a normal phenotype and were non-tumourigenic when injected into nude mice. However, contrary results of an increased or unaltered expression of integrins in transformed malignant cells in in vitro studies have been reported. For example, the malignant transformation by $\mathrm{N}$-methyl- $\mathrm{N}$-nitrosoguanidin in human osteosarcoma cells results in an increased expression of the $\alpha_{1}, \alpha_{2}$, and $\alpha_{6}$ chains. ${ }^{29}$ Thus, it seems clear that malignant transformation can affect the expression, distribution, and probably the functioning of cell adhesion components of the integrin class, but the pattern of changes may be complex.

Our results indicate a sequence of alterations in integrin expression during the transformation of normal colonic mucosa via adenomas into colorectal carcinomas. Firstly, the transformation to adenomas was characterised by a diminished expression of $\alpha_{3}$, and $\alpha_{5}$ chains of the VLA complexes (Fig 2), and secondly, the transformation from adenomas to carcinomas was characterised by a diminished expression of $\alpha_{6}$ chain (Fig 1). These changes could be the result to a series of genetic events which have been recently described in colorectal cancer. ${ }^{30}$ An activation of ras oncogenes is observed at an early stage in the course of the adenomacarcinoma sequence in the human intestine. Approximately $50 \%$ of adenomas larger than $1 \mathrm{~cm}$ in size have been found to have ras gene mutations. ${ }^{31}$ Oncogenic transformation of rodent fibroblasts with Rous-sarcoma virus or murine sarcoma viruses encoding ras oncogens led to a reduction of the expression of $\alpha_{5} \beta_{1}$ in these cells, 
whereas the $\alpha_{3} \beta_{1}$ expression was retained by the transformed cells. ${ }^{32}$

The second most common region of genetic alteration in colorectal tumours is in chromosome $18 \mathrm{q}$, which is changed in more than $70 \%$ of carcinomas. Using the polymerase chain reaction in an exon connection strategy, Fearon et al identified the altered sequence mapping as $18 \mathrm{q} .^{33}$ This gene, termed the DCC gene (deleted in colorectal carcinomas), encodes a protein with significant homologies to members of the family of cell adhesion molecules. ${ }^{3+}$ Therefore, the DCC gene might play a role in the development of colorectal tumours, perhaps through changes in physiological cell-cell and cell-matrix interactions. However, this speculation as well as the relation between the genetic changes and the diminished expression of integrins in human colorectal adenomas and cancers remain to be investigated.

\section{ADDENDUM}

After submission of this manuscript, Koretz et al, reported that VLA- $\mu_{6}$ expression in adenomas and carcinomas resembled that of normal mucosa using the immunoperoxidase technique (Koretz $\mathrm{K}$, Schlag P, Boumsell L, Möller P. Expression of VLA- $\mathrm{a}_{2}$, VLA$\alpha_{6}$ and VLA- $\beta_{1}$ chains in normal mucosa and adenomas of the $\alpha_{6}$ and $V L A-\beta_{1}$ chains in normal mucosa and adenomas of the colon, and in colon carcinomas and their liver metastases. Am $\mathcal{F}$ Pathol 1991; 138: 741-50). The fact that most malign lesions were mot stained using the immunofluorescence technique does not mean that cancerous cells did not contain VLA-6. The negative
cells may have had levels of receptor below the sensity of the cells may have had levels of receptor below the sensity of the
technique we used. However, our data demonstrated a significant technique we used. However, our data demonstrated a significant
decrease in $\alpha_{6}$ expression during the adenoma-carcinoma sequence.

1 LaMont JTh, Isselbacher KI. Diseases of the small and large intestine. In: Petersdorfer RG, Adams RA, Braunwald E, Isselbacher KJ, Martin JB, Wilson JD, eds. Harrison's principles of internal medicine. New York: McGraw-Hill. 1984: 1752-65.

2 Liotta LA, Rao CN, Barsky SH. Tumor invasion and the extracellular matrix. Lab Invest 1983; 49: 636-9.

3 Terranova VP, Liotta LA, Russo RG, Martin GR. Role of laminin in the attachment and metastasis of murine tumor cells. Cancer Res 1982; 42: 2265-9.

4 Buck CA, Shea E, Duggan K, Horwitz AF. Integrin (the CAST antigen): functionality requires oligomeric integrity. f Cell Biol 1986: 103: 2421-8.

5 Carter WG, Wayner EA, Bouchard TS, Kaur P. The role of integrins $\alpha_{2} \beta_{1}$ and $\alpha_{3} \beta_{1}$ in cell-cell and cell-substratum integrins $\alpha_{2} \beta_{1}$ and $\alpha_{3} \beta_{1}$ in cell-cell and cell-substratum adhesion of

6 Hynes RO. Integrins: a family of cell surface receptors. Cell 1987; 48: 549-54.

7 Albelda S, Buck CA. Integrin and other cell adhesion molecules. FASEB F 1990; 4: 2868-80.

8 Ginsberg MH, Loftus JC, Plow EF. Cytoadhesins, integrins and platelets. Thromb Haemost 1988; 59: 1-6.

9 Kramer RH, McDonald KA, Vo MP. Human melanoma cells express a novel integrin receptor for laminin. $7 \mathrm{Biol}$ Chem 1989; 264: 15642-9.

10 Kajiii S, Tamura RN, Quranta V. A novel integrin $\left(\alpha_{\mathrm{E}} \beta_{1}\right)$ from human epithelial cells suggests a fourth family of integrin adhesion receptors. EMBO f 1989;8: 673-80.
11 Sonnenberg A, Linders CJT, Modderman PW, Damsky CH, Aumailly M, Timpl R. Integrin recognition of different cellbinding fragments of laminin (P1, E3, E8) and evidence that $\alpha_{6} \beta_{1}$ but not $\mu_{6} \beta_{4}$ functions as a major receptor for fragment $\alpha_{6} \beta_{1}$ but not $\alpha_{6} \beta_{4}$ functions as a ma
E8. 7 Cell Biol $1990 ; 110: 2145-55$.

12 Choy MY, Richman PI, Horton MA, MacDonald TT. Expression of the VLA family of integrins in humane intestine. Pathol 1990; 160: 35-40.

13 Stallmach A, Riese HH, Schuppan D, Bornhoeft G, Stein H, Riecken EO. Identification of different laminin-binding proteins in basolateral cell membranes of human colo-recta carcinomas and normal colonic mucosa. Gut 1991; 32 282-6.

14 Pignatelli M, Smith MEF, Bodmer WF. Low expression of collagen receptors in moderate and poorly differentiated colorectal carcinomas. Br F Cancer 1990; 61: 636-8.

15 Morson BC, Dawson IMP. Adenocarcinoma and other malignant epithelial tumours. In: Gastrointestinal pathology. Oxford: Blackwell Scientific. 1985: 648-80.

16 Hemler ME, Jacobson JG, Strominger JL. Biochemical characterization of VLA-1 and VLA-2. F Biol Chem 1985; 260: $15246-52$.

17 Zutter MM, Mazoujian C, Santoro SA. Decreased expression of integrin adhesive protein receptors in adenocarcinoma of the breast. Am F Pathol 1990; 137: 863-70.

18 Morhenn VB, Schreiber AB, Soriero O, McMillan W, Alliso AC. A monoclonal antibody against basal cells of human epidermis. Potential use in the diagnosis of cervical neoplasia. F Clin Invest 1985; 76: 1978-83.

19 Hemler ME, Huang C, Takada Y, Schwarz L, Strominger JL, Clabby ML. Characterization of the cell surface hetreodimer VLA-4. F Biol Chem 1987; 262: 11478-85.

20 Wayner EA, Carter WG, Piotowicz RS, Kunicki TJ. The function of multiple extracellular matrix receptors in mediating cell adhesion to extracellular matrix: Preparation of monoclonal antibodies to the fibronectin receptor that monoclonal antibodies to the fibronectin receptor that specifically inhibit cell adhesion ot fibronectin and react with
platelet glycoproteins Ic-IIa. $\mathcal{F}$ Cell Biol 1988; 107: 1881-91.

21 Sonnenberg A, Modderman PW, Hogervorst E. Laminin receptor on platelets is the integrin VLA-6. Nature 1988 336: 487-9.

22 Morimoto Letvin NL, Boyd AW, Hagan M, Brown HM Kornacki MM, et al. The isolation and characterization of the human helper inducer T cell subset. F Immunol 1985 134: 3762-9.

23 Hildreth JEK, Gotch FM, Hildreth PD, McMichael AJ. A human lymphocyte-associated antigen involved in cell mediated lympholysis. Eur F Immunol 1983; 13: 202-8

24 Ruan C, Du X, Wan H, Hu X, Xi X, Li P. Characterization of the human platelet membrane glycoproteins IIb/IIIa. The human platelet membrom

25 Hessle H, Sakai LY, Hollister DW, Burgeson RE, Engvall E. Basement membrane diversity detected by monoclonal antibodies. Differentiation 1984; 26: 49-54.

26 MacDonald TT, Horton MA, Choy MY, Richman PI. In creased expression of laminin/collagen receptor (VLA-1) on epithelium on inflamed human intestine. $\mathcal{F}$ Clin Pathol 1990 43: 313-5.

27 Costantini RM, Falcioni R, Battista P, Zypi G, Kennel SJ, Colasante $A$, et al. Integrin $\left(\alpha_{6} / \beta_{4}\right)$ expression in human lung cancer as monitored by specific monoclonal antibodies. Cancer Res 1990; 50: 6107-12.

28 Giancotti FG, Rouslahti E. Elevated levels of the $\alpha_{5} \beta_{1}$ fibronectin receptor suppress the transformed phenotype of nectin receptor suppress the transformed phen

29 Dedhar S, Saulnier R. Alterations in integrin receptor expression on chemically transformed human cells. 7 Cell Biol $1990 ; 110: 481-9$.

30 Fearon ER, Vogelstein B. A genetic model for colorectal tumorigenesis. Cell 1990; 61: 759-67.

31 Vogelstein B, Fearon ER, Hamilton SR, Kern SE, Preisinger AC, Leppert $M$, et al. Genetic alterations during colorectaltumor development. N Engl F Med 1988; 319: 525-32.

32 Plantefaber LC, Hynes RO. Changes in integrin receptors on oncogenically transformed cells. Cell 1989; 56: 281-90.

33 Fearon ER, Cho KR, Nigro JM, Kern SE, Simons JW, Ruprecht JM, et al. Identification of a chromosome 18q gene that is altered in colorectal cancers. Science 1990; 247: 49-56.

34 Edelman GM. Morphoregulatory molecules. Biochemistry 1988; 27: $3534-43$. 